University of Nebraska - Lincoln

DigitalCommons@University of Nebraska - Lincoln

Faculty Publications - Department of English

English, Department of

2008

The Beginnings of the American Novel

Melissa J. Homestead

University of Nebraska-Lincoln, mhomestead2@Unl.edu

Follow this and additional works at: https://digitalcommons.unl.edu/englishfacpubs

Part of the English Language and Literature Commons

Homestead, Melissa J., "The Beginnings of the American Novel" (2008). Faculty Publications -Department of English. 79.

https://digitalcommons.unl.edu/englishfacpubs/79

This Article is brought to you for free and open access by the English, Department of at DigitalCommons@University of Nebraska - Lincoln. It has been accepted for inclusion in Faculty Publications -- Department of English by an authorized administrator of DigitalCommons@University of Nebraska - Lincoln. 
Published, as Chapter 23, in The Oxford Handbook of Early American Literature, ed. Kevin J. Hayes (New York: Oxford University Press, 2008), pp. 527-546.

Copyright (C) 2008 Oxford University Press. Used by permission.

\title{
The Beginnings of the American Novel
}

\author{
Melissa J. Homestead \\ University of Nebraska-Lincoln
}

In September 1742, Edward Kimber left England for North America, arriving in New York City in November. During a sojourn of nearly two years, he traveled widely, south from New York to Maryland, Virginia, Georgia, and St. Augustine, Florida, and then northward from Florida to Charleston, South Carolina, whence he returned to England, arriving in July 1744. His Itinerant Observations in America appeared serially in the magazine his father edited, the London Magazine, from August 1745 through December 1746 (Kimber 1998,11-15). As becomes clear in his Itinerant Observations, earlier encounters with representations of North American landscapes and people in English print culture framed his perceptions and motivated his desire to travel America to experience it firsthand. For instance, when describing the beauties of the landscape along a road to the dividing line between the Maryland and Virginia colonies, he interjects: "And here I can't help quoting Mr. Lewis, when speaking of another Road in this Colony" (Kimber 1998, 52). He quotes several lines from the poem "A Journey from Patapsco to Annapolis, April 4, 1730," by American poet Richard Lewis, and then, returning to narrating the "present" of his ongoing American journey, he remarks, "Indeed, I can't help, every now and then, taking him out of my Pocket in this Country; for his descriptive Part is just and fine, and such a Warmth of Sentiment, such a delicate Vein of Poetry, such an unaffected Piety runs thro' the Whole, that I esteem it one of the best Pieces extant" (Kimber 1998, 52). 
How did an American poem about a Maryland scenic prospect end up in Edward Kimber's pocket, and what does his reading of it in Maryland have to do with the beginnings of the American novel? Lewis's poem first appeared in print in the North American colonies, but Kimber likely carried a clipping of the poem as it had appeared in his father's London Magazine in 1733, his father having reprinted it from the Weekly Register of London (Kimber 1998,11). This anecdote thus gestures to the complex transatlantic circulation of persons, texts, and stories. Even more telling, however, for the history of the American novel is an adjacent anecdote in Kimber's Itinerant Observations about the life of "Capt.

Master of —_, who had been kidnapped off the streets of London sixty years earlier. The ship's captain, who kidnapped him as a boy, subjected him to sexual abuse on the voyage across the Atlantic, and then sold him to a Maryland planter "for 14 years for 12 Guineas." Kimber commits to writing Captain —_s story "as I had it from the very Person himself, who is the chief in the Story" (Kimber 1998, 50). The planter treats the boy as his own son and places advertisements in London newspapers in hopes of locating his parents. These efforts fail, but the boy marries his master's daughter and prospers as a planter. By chance, he buys his kidnapper at a convict auction. Unfortunately, the kidnapper can provide no information about his parents, and the kidnapper commits suicide rather than labor for the man he wronged. A decade after Kimber recorded Captain 's life story for magazine publication, he transformed some of these incidents into a novel published in London, The History of the Life and Adventures of Mr. Anderson. Containing His Strange Varieties of Fortune in Europe and America. Compiled from His Own Papers.

More than two decades after Edward Kimber crossed the Atlantic from England to the colonies, young Susanna Haswell (later Rowson) made her first transatlantic crossing in 1766, four years after her birth in Portsmouth, England, to join her father and his second wife in America. Susanna spent her childhood and early adolescence in Massachusetts in the run-up to the American Revolution. During the war, her father's Royal Navy affiliation drew the suspicions of local patriots, who relocated the family inland and kept them as quasi prisoners from 1775 through 1778, finally exchanging the Haswell family for American prisoners of war (Parker 1986,1-8). As an adult, Rowson, like Kimber, made American people and places the subject of a novel first published in London, Charlotte, $A$ Tale of Truth (1791). Her novel, like Kimber's, also features a central character who crosses the Atlantic at a young age under duress. A student at an English boarding school, Charlotte receives illicit romantic attentions from a British army officer, Montraville, who maneuvers her into an elopement to America when his army duties take him to New York City during the Revolution. Charlotte dies, seduced and abandoned, before she can return to England and her parents. However, her father crosses the Atlantic and finds her on her American deathbed, agreeing to take her illegitimate infant daughter back to England. 
In a fitting reversal of Charlotte's trajectory, Susanna Rowson carried her literary offspring - a copy of the British edition of Charlotte - to the new United States of America in 1793. Charlotte was practically stillborn on the British market-the 1791 London edition seems to have sold relatively poorly, with only one copy of it known to exist today (Davidson 1989, 167-168, 175). Imported copies of the novel preceded Rowson to the United States, with Charlotte appearing in booksellers' and libraries' catalogs in New York, Philadelphia, and Boston in 1792 and 1793, including Mathew Carey's Philadelphia bookstore in 1792 (Vail 1932,77). However, Carey did not publish an American edition until Rowson herself appeared in Philadelphia, having been recruited in London to join a Philadelphia theater company as an actress. Published under Carey's imprint in 1794, the novel became, by some accounts, "the first American best-seller" and Rowson "the first American to succeed in the literary marketplace" (Parker 1986, i). Retitled Charlotte Temple in 1797, the novel appeared in many American editions and remained widely available through the nineteenth century (Rowson 1986).

Charlotte Temple and Mr. Anderson do not, however, appear together in most accounts of the history of the American novel. For most of the twentieth century, such histories began in 1789, with the publication of William Hill Brown's tale of seduction, The Power of Sympathy, which, as Alexander Cowie describes it, is "a comparatively long fictional work laid in Boston, published in Boston, written by an American, and grounded in purely local interests" (Cowie 1948, 10). Analyses of the American novel covering the 1790s most often focus on Hugh Henry Brackenridge's satiric picaresque of early national politics, Modern Chivalry (published in sporadic installments beginning in 1792); Hannah Webster Foster's fact-based seduction novel, The Coquette (1798); the early novels of Charles Brockden Brown, whose career as a novelist began in 1798; and Charlotte, with foreign-born Charlotte taking the place of "an adopted child in a family of biological siblings" all born in America (Stern 1997, 34). Literary history has also, however, often characterized these early novels and others published during the same years as botched or confused. Critics attribute the failure of the early nation to produce novels worth reading and valuing to many factors, such as the moral and religious censure of novel reading, the dispersal of the population across a broad geographic area, the absence of some cohesive American identity capable of expression in literature, and a continuing colonial dependence in cultural matters even after the Revolution (Loshe 1907; Cowie 1948; Fiedler 1960).

Critical judgments shifted in the late twentieth century. Instead of explaining why these stories of seduction, incest, picaresque wandering, and gothic intrigue are pale, belated imitations of British antecedents, critics have analyzed these novels in light of the pressing political questions facing the new nation in the wake of the enactment of the U.S. Constitution in 1789 (Davidson 1986; Stern 1997; Barnes 1997). Other critics have reassessed the chronological and geographic boundaries of the American novel, looking at novels produced as early 
as the late seventeenth century and representing life in North America, South America, and the West Indies. This chapter strikes a geographic and chronological middle course, focusing on novels published from the 1750s into the 1790s that represent life in the British colonies that became the United States of America, even though most of these novels were first published in London, not the colonies or the United States. Indeed, this chapter argues that the American novel as traditionally defined (set in America, treating American subject matter, written by an American person) necessarily had its beginning from within a transatlantic context. These early novels feature significant American content involving major characters, but they were also written by authors who resided for some period in what would eventually become the eastern United States - or were written by persons who represented themselves in print as having resided there. In addition to Mr. Anderson and Charlotte, this chapter considers Charlotte Lennox's The Life and Adventures of Harriot Stuart, Written by Herself (1750); Emmera, or. The Fair American (published anonymously in 1767, but by Arthur Young); The Female American (also published anonymously in 1767, represented as the edited papers of Unca Eliza Winkfield, a seventeenth-century American woman); and two other Rowson novels of the 1790s.

Julie Ellison has identified a plot trajectory in a number of late eighteenth-century novels she calls "there and back": the central characters of these transatlantic fictions begin in England but leave for the British North American colonies (there), where they recover their fortunes by engaging in colonial enterprise and then return "back" home. Ellison also finds this trajectory in the careers of authors of such novels, including Lennox. Tracing plot trajectories and authorial careers, and adding publishing history and readership, this chapter maps multiple patterns of transatlantic circulation, some of which end with a return to the metropole, but others of which end in the colonies or the American nation. Plots, careers, and publishing history sometimes synchronize, but often these patterns of circulation conflict and compete, and in this conflict and competition, the American novel begins.

Many other novels potentially fall into the category of what might be called the proto-American novel. Daniel Defoe's Moll Flanders, for instance, published in 1721, takes the tide character to Virginia. Defoe based his depiction of Virginia entirely on secondary sources rather than personal experiences, but the original readers of his anonymously published novel (presented as the first-person memoirs of Moll herself) would not have been able to draw such a distinction. Furthermore, countless other eighteenth-century English novels include American materials, from subplots to mere verbal references (Heilman 1937; Bissell 1925). Still, a slightly narrower focus allows us to ask a pertinent question: before the American Revolution, why weren't novels based on the American experiences of their authors published in New York, Boston, or Charleston rather than in London?

Edward Kimber was firmly planted in England at the time he wrote and published Mr. Anderson, and his trip to America seems to have been a gambit for ac- 
quiring and importing literary material from America to England, with no intention of Kimber himself acculturating; his career trajectory was unambiguously "there and back." In a broader sense, however, the London publication of such "American" novels speaks to the economic and material constraints on printing and publishing in the colonies. Literary historians often cite the fact that the first novel printed in America was Benjamin Franklin's edition of Samuel Richardson's Pamela, published in London from 1740 to 1741 and issued in installments in Philadelphia from 1742 to 1743 . What they fail to mention, however, is that Franklin's Pamela was a financial failure and was thus the only novel printed in unabridged form in the American colonies until the late 1760s (Hall 1996, 268269,288 ; Wolf 1988, 188). Because of the high cost of type, paper, and labor in the colonies, printing most books was simply too expensive-printers rarely risked the substantial investment required to print books when they could be imported from London (or from piratical publishers in Dublin) much more cheaply. When colonists read novels, they thus purchased ones imported from London (or Dublin) or, especially later in the century, borrowed such imported copies from circulating libraries (Winans 1975). As Robert Winans has demonstrated, even when American printers other than Franklin began to reprint English novels in the last third of the eighteenth century, "The longer the novel the less likely it was to have been printed in America in even one unabridged edition" (Winans 1983, 181). Indeed, even after the Revolution and peace with England, importing novels remained cheaper, in most cases, than printing them in America until into the very early nineteenth century (Hall 1996, 195-196). Colonial Americans who aspired to write something that might be called an American novel would have had to seek out publishers across the Atlantic in order to address their American neighbors from between the covers of a book-length fiction.

Even before the 1750s, we can catch a glimpse of an imagined transatlantic author-reader address in 1723, when Arthur Blackamore's Luck at Last; or, The Happy Unfortunate was published in London. An Oxford graduate, Blackamore emigrated to the Virginia colony in 1707 and served for a decade as master of the Grammar School of the College of William and Mary. The board of governors of the school repeatedly censured him for his drinking, and he finally returned to England, apparently with the hope of taking orders in the Church of England and returning to Virginia as a clergyman (Hayes 1998). Luck at Last features no American scenes or characters and is, in fact, derived from Aphra Behn's short prose romance The Wandering Beauty, published after her death in 1698. However, in his preface, Blackamore addresses the novel to "the ingenious Mr. David Bray, Merchant of Virginia," Bray being an actual person whose age suggests that he had been one of Blackamore's grammar school students. "You have formerly known me better than to imagine I would write this out of flattery, after the common method of most modern dedicators," he writes. "For had my talent lain that way [in the way of flattery] , I had probably fared more successfully in some particular affairs when I was in America." He suggests a resemblance between one particu- 
larly admirable character and Bray's deceased mother, and he asks leave "to commit The Happy Unfortunate into your hands. And if you shall be pleased to give it a perusal at your leisure hours and a candid admission into your study" (Davis 1967, 22-26, 33; McBurney 1963, xvi, 3-4). Although Blackamore's attempts to return to Virginia in the flesh had not succeeded, he imagines the London publication of his novel as effecting his return to Virginia in print.

The 1750s marked the appearance of Kimber's Mr. Anderson and Charlotte Lennox's Harriot Stuart, both of which draw on the authors' experiences of the American colonies in the previous decade (Kimber also drew on his American experiences to a lesser extent in his novel The Life and Adventures of Joe Thompson [1750], while Lennox returned to her American experiences in her epistolary novel Euphemia [1790]). The plots of Mr. Anderson and Harriot Stuart both follow the "there and back" trajectory, as do their authors' careers, and both novels draw on personal experience as well as a variety of sources circulating in transatlantic print culture, including piracy and Indian captivity narratives (Howard 1993; Ebersole 1995, 98-128). The story of Captain — reported in Kimber's Itinerant Observations is certainly not the only source for Kimber's novelistic account of Thomas Anderson's life (Mason and Mason 2007). But the manner in which Kimber grafts the "there and back" trajectory onto the basic outlines of Captain _ 's life reveals Kimber's investment in a version of a colonial narrative that ultimately returns the fruits of colonial enterprise to England. Captain — never discovered the identity of his parents and was firmly ensconced on his plantation in Maryland, but Kimber engineers a reunion between his title character and his family in England, the Andersons. The man who discovers his identity as Thomas Anderson dissolves his colonial holdings and transports his wife and adoptive family "back" to England.

Nevertheless, the complete geographic trajectory of Tom's life is far more complex than "there and back" implies. After being kidnapped and transported to Maryland as a child, Tom matures to young adulthood in the Barlow family under a cruel master and his kind wife and daughter, Fanny, who treat him as an adopted son and brother. Expelled by Barlow to prevent his marrying Fanny, Tom becomes the adopted son of the man who buys him from Barlow, Matthewson, an Indian trader. With Matthewson and then after Matthewson's death (which leaves Tom a wealthy man), he participates in armed conflict with the French and their Indian allies. Throughout the American episodes, Kimber specifies dates and places with precision, placing Tom in the midst of actual historical events. Kimber even adds footnotes about unusual American flora and fauna (although this information is not always accurate with respect to parts of America Kimber had not studied closely at firsthand [Milne 1947, 248-249]). Tom marches twice from Virginia to Quebec, the first time in a military maneuver and the second time as a captive. The French governor sends captive Tom from Quebec to France, by way of the West Indies, where Tom assists in the capture of an English pirate ship, on which his childhood kidnapper, John Williamson, is a member of 
the crew. As with Captain — of Kimber's Itinerant Observations, his kidnapper can provide no information about Tom's parents. Set free in France, Tom spends months there before moving on to England, where coincidence leads him to a reunion with his biological parents, the Andersons, a discovery that makes him future heir to yet another large estate. However, he resolves to return to America, to find "His dear Fanny, absence from whom was now the only care or concern he had, at length again resumed empire in his heart, and he found he must see her or dye" (Kimber 1754, 185). On his newly discovered father's ship, he returns to America, where he marries Fanny and takes her and her mother back to England, where they live happily ever after.

This brief summary only begins to trace the multiple transatlantic crossings that litter the pages of the text, including the interpolated life stories of the people Tom meets in his adventures. Additionally, the novel pays close attention to the transatlantic circulation of texts, in both manuscript and print, and to other arcane details of the networks of exchange that connect (or fail to connect) persons separated by the Atlantic Ocean. Kimber introduces the "good" Marylanders by their libraries of fine imported books. Mrs. Barlow's unusually fine education (superior to that of her husband) is evidenced by her "pretty female collections of the politest authors, in whom Fanny and Tom amused themselves so much, that their ideas of men and things began to open surprisingly." Their benevolent neighbor Mr. Gordon, a Scotch clergyman, "had brought a tolerable library into the country, and had since much enlarged it by orders from England, and promised to let them have one by one his whole riches, as their increasing years fitted them for their perusal." When Mr. Barlow sends Tom into exile to be an overseer at one of his distant plantations, another kind neighbor, Mr. Ferguson, brings, as he tells Tom, "a quire of paper, some pens, and some ink, in my bag, and in my pocket Horace ... to alleviate and brighten some of your solitary hours" (Kimber 1754, 22-23, 74-75).

Although Tom successfully communicates with Mrs. Barlow and Fanny by means of these supplies, his adventures and the adventures of others turn on failed transatlantic communications. Mr. Ferguson, for instance, sends a letter to Paris informing Tom of what has happened to the Barlows in his years away from Maryland, but the ship carrying the letter burns before it reaches France, leaving him unsure of whether Fanny's father succeeded in forcing her into marrying another. The mechanisms through which Thomas transports his accumulating wealth from America, to France, and on to England succeed, however. Although Ferguson's letter does not arrive in Paris, Tom does receive a letter and funds from his agent back in Virginia per his instructions sent from Canada. The coincidence that leads him to his parents involves another such transaction - he unknowingly employs his own father as his financial agent in London. In a fitting gesture mirroring Tom's access to two imported libraries during his years in service in Maryland, his final gesture in Maryland involves a gift of imported books: "Mr. Anderson presented to Mr. Gordon and Mr. Ferguson the library he 
had purchased for them [in France and England], as a joint possession between them, which cost him near $£ 150$ " "Mr. Anderson" goes "back" to England, but not the new owners of the library, who reject Tom's offer to be "sharers in all his fortune" because "they were now quite wedded to the country and the climate ... and did not choose to remove to Europe" (Kimber 1754, 143, 150).

Of course, Mr. Kimber did go back to England after his American sojourn, as did Charlotte Ramsay, and both used resources from their colonial ventures as literary material for their fiction. As a young adolescent in a marginally genteel American family, Charlotte Ramsay had experiences that did not range as widely as Kimber's. Scholars disagree about the precise details of her early life and the degree to which her life and the life of the eponymous heroine of Harriot Stuart intersect. Charlotte Ramsay was likely born in Gibraltar in the late 1720s when her army officer father was stationed there. After some years in England, her father's military responsibilities took his family to the New York colony, where her father was assigned to the fort at Albany. She spent at least three, possibly more, years there in the late 1730s and early 1740s, returning to England as a young woman and marrying Alexander Lennox in 1747. Although Lennox later in life claimed a birth date of 1720, recent research has made it clear that when she wrote Harriot Stuart in 1750, she was the age of her young heroine at the close of the novel, about twenty years old (Carlile 2004).

Harriot Stuart, presented in the form of a long letter-memoir to "Amanda," a friend of the heroine, commences when Harriot is eleven years old. A preternatural coquette, Harriot looks forward to her father's post in America and "his design of settling there ... with a childish pleasure" (Lennox 1995, 67). The space of the Atlantic between New York and England figures significantly in the tangled romantic intrigues in which Harriot becomes implicated. On the ship that takes Harriot and her family to New York, she first meets Dumont, the man she will marry several years later, but whose life is ensnared in a transatlantic romantic double bind. Dumont was born in New York, but his family destined him at birth for marriage with a female cousin back in England. Dumont has been carrying on a notorious public affair in New York with Mrs. B_- a married woman living there although her husband lives in Jamaica, where he is a wealthy planter. During her years in New York, Harriot circulates between New York City, A (Albany), and S — (Schenectady). Her geographic circulation overlaps with her romantic circulation as she turns away a man approved by her family, attempts to elope with a man of whom they disapprove, and is kidnapped by another, who effects the kidnapping disguised as an Indian and assisted by Indians. When her father dies leaving his wife and two daughters in financial straits, Mrs. Stuart sends her young daughter alone to England, where Harriot's aunt, widow of a baronet, promises to take her in and treat her as her own daughter. On her return passage to England, a Spanish privateer captures the ship, but it is the captain of the British ship that takes the privateer, not the Spanish pirates, who threatens Harriot's stillpreserved chastity. The nearly deadly stab wound she inflicts upon the captain foils 
his attempted rape, but when Harriot arrives in England, she discovers that her aunt has gone mad, thus frustrating her hopes of a new and genteel home.

Harriot never returns to America in the course of the novel (although Dumont's English Catholic relatives do have her trepanned and held captive in a French convent, among other extraordinary adventures), and the novel culminates with everyone settled (and wealthy) in England. And despite the fact that she wrote this novel within a few years of her own American experiences, critics have found her representations of the New York colony disappointingly thin. Julie Ellison, for instance, all but dismisses Harriot Stuart as a transatlantic fiction because "the social world it portrays is indistinguishable from London" (Ellison 1995, 307). Like other critics, Ellison finds Lennox's fictional representation of New York in Euphemia, published long after her personal experience of the place, much richer and more substantive than her novel written with New York fresh in her mind (Howard 2005, 273; Berg 1996; Séjourné 1967, 118, 155). However, the seeming thinness of local color also reflects Lennox's accurate diagnosis of the lives of the class of colonial functionaries central to her novel. As Eve Tavor Bannet observes, Lennox unmasks "the profound economic and social insecurities at home and abroad which led liminally aristocratic Britons to fall back on gentility and polite manners both to signify a governing personal and national superiority, and to gain the edge in competition with other nations for colonial resources" (Bannet 1999, 74). That is, the social world in which Harriot Stuart circulates in New York is "indistinguishable from London" precisely because the colonials are anxiously replicating London manners on American soil.

Lennox, based both on her life experiences and on her novels representing colonial New York, deserves the title Philippe Séjourné bestows on her, "First Novelist of Colonial America." Despite bestowing this title, he wonders whether Harriot Stuart's extraordinary character was possible, "only because she lived in a very different world from that of her readers?" (Séjourné 1967, 99). Looking at the other side of the coin and confronting the apparent lack of success the novel found with readers in England, he hypothesizes, "Harriot Stuart would have been more of a success with the much freer society of New York, had the book ever been published there" (Séjourné 1967, 157). Lennox's representations of New York did not, however, circulate only in the metropole, as Séjourné assumes based on his mistaken conflation of place of publication with circulation and readership. In the 1750s and 1760s, Harriot Stuart was available in a Boston circulating library, was advertised for sale in South Carolina, and may have been included in William Byrd's private library in Virginia as light reading for his daughters (Hayes 1996, $115,174)$. Indeed, as an adolescent who surely read novels voraciously while residing in New York in the late 1730s and early 1740s, Lennox might have anticipated an American colonial audience for her colonial American novel.

Two strikingly fanciful novels of the 1760s, The Adventures of Emmera and The Female American, deserve consideration alongside Kimber's and Lennox's transatlantic novels even though they likely did not originate in their authors' direct experi- 
ences of the American colonies. Emmera consists entirely of letters between several groups of correspondents, with the majority of these letters traveling in the transatlantic mails between England and America. The novel bears two subtitles: the first, The Fair American, restates the notable characteristics of the beautiful young title character, Emmera; the second, Exemplifying The Peculiar Advantages of Society and Retirement, lays out the schematic oppositions of the novel. "Society" (also denominated "the world") signifies England, and "retirement" signifies America. Despite this supposedly clear opposition and separation between England and America, people and texts circulate between the two in dizzyingly intricate ways. The most prolific letter writer, young Sir Philip Chetwyn, in America because his father is considering relocating his family from England to northern New York, whiles away his time exploring the sublime wilds of the Ohio territory. By chance, he stumbles upon an English father and daughter who have constructed an elaborate pastoral retreat far beyond the habitations of white settlers. The dying father entrusts Emmera to Sir Philip's care, even though he lives in the world his father has forsaken. Before seeing Sir Philip, Emmera has seen no white man other than her father. Her father taught her to read, however, from the books he transported from England to the wilds, and he tells her many stories of the bustle of life in England (Young 1974, 29, 39-40). Among the pastoral delights Sir Philip experiences during his time with Emmera are reading Plutarch, Paradise Lost, and the Spectator aloud to her. Sir Philip sends many long letters singing Emmera's praises to Colonel Forrester in England, a man he believes to be his friend. However, Forrester actually considers Sir Phillip his enemy because Sir Phillip's sister Harriet refused a marriage proposal from him. Forrester thus uses Sir Philip's letters to plot a revenge trip to America. Meanwhile, Harriet carries on her own transatlantic correspondence with her friend Kitty Hervey, a young society woman who embodies the best of society and who counterplots against Forrester and his evil compatriot Edgerton.

A significant portion of the novel consists of a manuscript document that Sir Philip and Emmera find in the chest containing Emmera's small library, a lengthy account of her father's life, including his reasons for removing to America with his infant daughter. This document, which Sir Philip (implausibly) copies into a letter to Forrester, proves to be the key to every plot and subplot in the novel. The manuscript not only reveals Emmera's true identity but also reveals that Harriet's correspondent Kitty Hervey is Emmera's cousin and that the Hervey family is in illegitimate possession of Emmera's father's English estate. The villains decode the mystery first, and they attempt to use this information to their own advantage. By the close of the novel, most of the significant characters have sailed back and forth across the Atlantic at least once. The entire Chetwyn family, of course, has just crossed at the opening of the novel. Colonel Forrester crosses from England to America to humiliate Harriet and to wound Sir Philip by kidnapping Emmera (both plots fail, and he returns to England, where he aids a plot to claim Emmera's estate). After the failed kidnapping attempt. Sir Philip persuades Emmera to leave their seclusion, first to visit his father and sister and then even to 
cross the Atlantic, hoping to show her that it is possible to live in seclusion in the English countryside. His attempt at persuasion fails, but he succeeds in marrying her (the great obstacle to their marriage in their rural seclusion was the lack of an ordained Christian minister - Emmera regards nearby Indians as her "neighbors" and protectors, but, apparently, she still finds the ecclesiastical authority found only in society necessary to transform their platonic friendship into a conjugal union). Sir Philip and Emmera return to live in their American pastoral hermitage, but the novel ends with a letter to his friend Mr. Sinclair in England (now married to Harriet's correspondent Kitty Hervey) and with a clear future of transatlantic correspondence between these men who have chosen the opposing paths of society (England) and retirement (America).

In some ways, this epistolary novel of the 1760s appears more "American" than Harriot Stuart-if one takes the quantity of local color and descriptions of peculiarly American landscapes to constitute Americanness. Sir Philip's letters to Forrester feature a wealth of detail about American landscapes, as well as about the Indians living in the vicinity of Emmera's hermitage. However, much of this detail is extravagantly fanciful (Indians fight with broadswords, for example). Furthermore, the man who was almost certainly author of this novel, Arthur Young, never traveled to America and thus necessarily derived all this detail from secondary sources and from his fertile imagination. The novel (like $\mathrm{Mr}$. Anderson and Harriot Stuart) appeared anonymously, and in the eighteenth century, no readers or critics had any reason to connect the novel to Young, who, in any event, had not yet made his reputation as an agricultural writer and reformer at the time of the publication of Emmera in 1767. Ruth Perry, who makes a strong case for attribution of the novel to Young, reads the American setting of the novel as a sort of nostalgic projection by Young: in the face of the disappearance of small farms in late eighteenth-century England, Young imagines the perfection of small-scale agriculture on American soil (Perry 2004, 290-291, 334). Emmera is not a hunter-gatherer - she tends a bountiful small farm, using the same agricultural techniques Young would later advocate in his reform writings. Although twenty-first-century scholarship has established that Emmera is part derivative fantasy, part nostalgic projection, concocted by a man who never stepped foot in the American colonies, eighteenth-century readers could have imagined otherwise. Furthermore, the novel had eighteenth-century readers in the colonies as well as in England - on the eve of the American Revolution, this novel celebrating America as an idealized space still open to the kind of small, independent farmers who were fast disappearing in England circulated in the American colonies (in English-produced copies) shortly after its publication in England. When Lewis Nicola opened the first commercial lending library in Philadelphia on September 10, 1767, for example, he advertised the work as newly arrived from London and available for borrowing (Wolf 1988,193). The conclusion of Emmera, like Kimber's Mr. Anderson, imagines that some colonials might choose America in preference to a return to England. 
Lewis Nicola also advertised the availability of The Female American in September 1767. The novel, like Emmera, first appeared in London in 1767, but the identity of the author remains a mystery. Like so many eighteenth-century novels (including Harriot Stuart), the novel takes the form of a first-person narrative presented as an authentic document. As the subtitles indicate, the novel consists of The Adventures of Unca Eliza Winkfield, Compiled by Herself. In this respect, The Female American also resembles the very famous eighteenth-century novel it imitates, Daniel Defoe's Robinson Crusoe, with a "female American" of mixed English and Native American ancestry stranded on an island in the Atlantic substituted for Defoe's Englishman. Unlike Robinson Crusoe (or Harriot Stuart), however, the novel does not frame the "authentic" memoir as having been written at a time roughly contemporaneous with its publication. In the brief "Advertisement" preceding the novel, "The Editor" presents the "following extraordinary History" as a printed version of a memoir "I found ... among the papers of my late father" (Winkfield 2001, 33). The advertisement thus presents the text as a historical curiosity authored by a person (Unca Eliza Winkfield) long dead. As Laura Stevens points out, the novel thus complexly balances three distinct historical moments: it is "set in the seventeenth century" and presented as having been written at the conclusion of the seventeenth-century events described; it "imitates an early-eighteenth-century novel" (Robinson Crusoe); and it was published in the late eighteenth century, "in the decades of tension preceding the American Revolution" (Stevens 2005, 142).

The bulk of the novel takes place on an island in the Atlantic Ocean vaguely situated off the coast of the Americas. However, the Virginia Colony in continental North America serves as an important fulcrum in Unca Eliza's life. Unca Eliza is born in Virginia to a white English settler father, William Winkfield (son of the governor of the colony, Edward Maria Winkfield), and an Indian mother (Unca, daughter of the unnamed "king" of the local tribe). As Michelle Burnham notes, this genealogy makes Unca Eliza "the fictional granddaughter of an actual historical figure"; Edwin Maria Wingfield (Winkfield being an alternate spelling) was the historical first governor of Virginia. William and Unca first meet when she saves him from beheading by men of her tribe, an incident that clearly echoes Captain John Smith's account of his rescue by Pocahontas, thus doubling Unca Eliza's mytho-historical ancestry. The novel passes very quickly over the six years of Unca Eliza's childhood in Virginia, and after an internal power struggle in her tribe results in the assassination of her mother, William Winkfield takes his daughter to England to live in the family of her uncle. William returns to Virginia after a year, leaving Unca Eliza in England until she is eighteen. In England, she adopts a "mixed habit" combining European and Indian traditions, becomes a pious Christian under the tutelage of her clergyman uncle, and acquires an education (including training in classical languages) unusual for an eighteenth-century woman. She is eighteen by the time she returns to her "native country" and to her father, who dies as he prepares to sell his estates and return to England with his daughter. Her 
third Atlantic crossing proves the charm - or the curse - that lands her on an "uninhabited island," where the ship's captain deposits her "to be prey to wild beasts" because she refuses to marry his son (Winkfield 2001, 24, 49, 51, 54).

The mixed cultural training of her first eighteen years ideally prepares her to survive and even thrive on this island as a chosen home. The captain allows her her trunk, which contains clothes and several books, and a bow and quiver of arrows. The books prove crucial. She derives spiritual sustenance from her Greek New Testament and uses an almanac to calculate the passage of time. The island turns out to have a single, year-round human resident, an English hermit, who dies soon after Unca Eliza arrives but leaves a lengthy manuscript guide to the island. In her account, Unca Eliza writes, "As I have this manuscript still in my possession, I shall do no more than give a very short view of its contents, though the whole of it would very well deserve to be made public " The novel itself serves as a sort of double of this hermit's manuscript. The hermit left England (for reasons unstated) and records his life with the intention of leaving this record on the island: "If this book should ever fall into the hands of any person, it is to inform him that I lived on this uninhabited island for forty years." By the end of the novel, Unca Eliza has used the information contained in the manuscript to effect the conversion of the Indians who periodically visit the island to perform religious ceremonies. After two years, her English clergyman cousin finds her, and they marry and stay on the island to minister to Unca Eliza's converts (or, rather, she steps down from the ministry she has been carrying out as a woman, a ministry that includes translating the Book of Common Prayer and the Bible into the language of her converts). First, however, her new husband returns to England to take leave of his family and to buy "a large library of books." When the ship leaves the island, it carries "these adventures" in the form of Unca Eliza's manuscript. That is, the "History" of Unca Eliza's adventures "The Editor" found "among the papers of my late father" were written on the island and transported to England (Winkfield 2001, 72, 58, 154-155, 33).

In 1767 the Critical Review expressed a wish that "Mrs. Unca Eliza Winkfield" had published "her" book in the wilds of America for the audience of "wild Indians to whom she is so closely allied" (Winkfield 2001, 192). The reviewer thus depicts Unca Eliza as an actual eighteenth-century person who sought print publication of her memoir. Furthermore, for this eighteenth-century critic, "America" seemingly signified broadly, encompassing both Unca Eliza's Virginia and her Atlantic island. More recently, Betty Joseph has persuasively argued the island on which most of the novel transpires should not be read as "America" in a more limited, modern sense. Instead, she claims, it is "a third space ... where the founding father has been displaced by the not-quite-white mother, and where Christianity becomes a female fantasy of total being that rescues the native population from the history of Anglo founding and Anglo (male) missionary projects" (Joseph 2000).

Readers in the American colonies and then the American nation, however, appropriated The Female American and made it into an "American" novel. Cathy Da- 
vidson has suggested that Charlotte Temple became "American" in the same way Rowson herself did, through a process of naturalization - both the novel and the author emigrated from England to America and were taken up by American readers as their own (Davidson 1989, 166-175). Like Emmera, The Female American was imported by American booksellers in 1767 (Wolf 1988, 193). The mid-1760s also marked the escalation of colonial resistance to the authority of Parliament in the wake of the Stamp Act, a resistance leading to the falloff of importation of Britishprinted books, including novels. Up until and through the American Revolution, American printers devoted their presses to politics and newspapers, not to printing novels (Hall 1996, 291-295). After peace with England, American printers reprinted British novels infrequently, returning instead to importation. Reprinting began to take off at the turn of the century, and in 1800, a printer in Newburyport, Massachusetts, issued an edition of The Female American. In 1814, the novel appeared in a second American edition printed in Vergennes, Vermont (Winkfield 2001, 29). Certainly, The Female American did not circulate as widely among American readers as did Charlotte, but readers (and printers) still appropriated Unca Eliza as their own, claiming both the person and her island as "American."

In light of this history of transatlantic fictions, Susanna Rowson's novels and career look more typical than exceptional. In particular, her two novels in addition to Charlotte featuring transatlantic content. The Fille de Chambre (also titled Rebecca, or, The Fille de Chambre) and Reuben and Rachel; or, Tales of Old Times, look back to this earlier literary genealogy. The latter, however, also looks forward to a new, self-consciously national American literary tradition. The Fille de Chambre was first published in 1792 for William Lane at the Minerva Press in London (one year after Lane published the first edition of Charlotte). Also like Charlotte, the original 1792 edition of The Fille de Chambre survives in only a single copy (and an incomplete one at that) and found more success with American readers than British. Rowson herself likely arranged the first American edition, which appeared in Philadelphia in 1794, and the novel appeared in several later American editions, both authorized and unauthorized (Weil 1976, 186; Vail 1932, 135137, 142-143).

Unlike the heroine of Charlotte, Rebecca, the chambermaid of the title, does not succumb to seduction. Forced to go into service because of her family's straitened finances, Rebecca fights off and evades multiple attempts at seduction and outright rape by titled gentlemen. She falls in love with Sir George, son of her first employer, Lady Mary Wroth, but Lady Mary extracts a promise from her never to hear professions of love from her son. After several years of service in various households (most of which she must leave because she becomes an object of seduction), she finally is reunited with Sir George and marries him, being conveniently absolved of her promise to Lady Mary on the grounds that Sir George is really not Sir George - the real Sir George was swiped from his cradle by Gypsies, and his nurse substituted the infant son of a poor widowed sailor. Mr. George Littleton, unlike Sir George, is a man of precisely her own class; he is 
even of her own family - he is her cousin, son of her father's brother, who left his infant in the care of a wet nurse when his wife died in childbirth.

Although most of the novel is set in England, several central chapters take place in a bucolic, idyllic town on the Massachusetts coast, where Rebecca lives contentedly with English émigrés the Abthorpes, who treat her as a friend and member of the family. Merging Rebecca's story with incidents derived from her own life, Rowson sets up this American idyll only to decry its destruction in the wake of the Revolution: "the unhappy breach between Great Britain and her colonies arose to such a height, that it never could be healed, and war, in her most frightful shape, began to stalk over this once happy land.... The son raised his hallowed arm against his parent, brothers drenched their weapons in each other's blood, and all was horror and confusion" (Rowson 1794, 119-120). Rowson did little or nothing to temper her language to suit post-Revolutionary American readers even in the first American edition of the novel (although she did add an apologetic preface to a "revised and corrected" edition [Rowson 1814]). She heaps anathema upon anathema on the patriotic cause, while occasionally praising the kindness of individuals she portrays as good people who were deluded into supporting a bad cause. Like Rowson's father, Mr. Abthorpe refuses to join the cause of the "enemies of his sovereign," and patriots divest the family of its property at gunpoint and march the family members inland "on pretence of his having held correspondence with the enemy." The narrator later commends young men who aid the family: "May the arrows of affliction with which an unnatural war has since wounded you, be drawn forth by the hand of sympathizing friendship, and the anguish of them obliterated by the recollection of your own good deeds." Indeed, supplying actual names of families from Hingham, Massachusetts, in the text and providing additional names in a footnote, Rowson uses the trials of Rebecca and the fictional Abthorpes to offer praise and thanks to those who aided the Rowson family. The American episode is relatively brief, however, with Rebecca returning to England and showing no intention at the end of the novel of ever leaving England. Perhaps, despite Rowson's harsh words for the Revolutionary cause, American readers found the reconstituted Littleton family attractive to their sensibilities. Offered a lucrative military post and potential for social advancement, the untitled George Littleton declines, explaining, "For my own part, though in the early part of life accustomed to all the indulgencies of an affluent fortune, I have been long convinced, that abundance of riches cannot secure happiness." Instead, with Rebecca and emulating her "humble spirit," he chooses to live in rural retirement (Rowson 1794, 126, 134-135, 205).

One might have expected Rowson's first novel both written and published in the new United States to feature American subject matter, but instead, Trials of the Human Heart (1795) subjects its heroine to suffering entirely on European soil. It was not until her next novel, Reuben and Rachel, published in Boston in 1798, that Rowson turned again to American scenes and characters. However, the novel is also her most insistently transatlantic, a sprawling, multigenerational saga the 
action of which spans time and place from Christopher Columbus's famous Atlantic crossing in 1492 to mid-eighteenth-century Philadelphia. In the more than three centuries between, Spaniards, Englishmen, South and North American Indians, Catholics, and several varieties of Protestants meet, intermarry, and migrate back and forth across the Atlantic. The title characters, twin brother and sister whose lives occupy most of the second volume, appear at the end of a tangled family tree that includes Christopher Columbus, the Incan king of Peru, an Algonquian chief, members of the Penn and Dudley families, and various other British nobles and aristocrats.

In her preface, Rowson explicitly states the patriotic motives behind her venture into historical fiction: "When I first started the idea of writing Tales of Old Times, it was with a fervent wish to awaken in the minds of my young readers a curiosity that might lead them to the attentive perusal of history in general, but more especially the history of their native country" (Rowson 1798, iii). By featuring Columbus so prominently in the family tree of Reuben and Rachel, Rowson participated with other post-Revolutionary American writers in a crucial shift in English representations of Columbus. Englishmen writing about the history of the exploration and settlement of British North America had claimed the ItalianSpanish explorer as their own as early as the sixteenth century. Before the Revolution, "Columbus" signified in English-language texts "the history of British America." After the Revolution, however, he signified "the early or prehistory of the new nation, transforming Columbus from the founder of an empire into the first citizen of an independent republic" (Spengemann 1994, 160).

What kind of republic does Rowson's Columbus found? Most notably, at the close of the novel, all the virtuous characters plant themselves firmly on the American side of the Atlantic Ocean - this novel ends "there," and only the corrupt go "back." "Where heaven-born Freedom holds her court / Let me erect my humble shed" directs the poetic quotation heading the final chapter, and Reuben, Rachel, their spouses, and sundry others do erect their (somewhat) modest homes in America, the land of freedom. Reuben and Rachel take possession of the Pennsylvania estate that their father acquired through his American business ventures, but they decline to accept the hereditary English estates long denied them during their period of greatest need: "As to titles," Reuben tells an English agent, we "renounce them; they are distinctions nothing worth, and should by no means be introduced into a young country, where the only distinction between man and man should be made by virtue, genius and education. Our sons are true-born Americans, and while they strive to make that title respectable, we wish them to possess no other" (Rowson 1798, 363).

The status of the aboriginal inhabitants of this "young country" at the close of the novel is debatable, however. The first volume's founding act is the marriage between the fictionalized son of Columbus and the daughter of a fictional Incan king, a marriage that produces Isabelle, a character who thus shares a status exactly analogous to that of Unca Eliza Winkfield of The Female American - she is the 
fictional mixed-race European-Indian granddaughter of an actual historical figure. Furthermore, in the first volume, many of the mixed-race descendants of this marriage self-consciously claim their dual racial and cultural heritage. In the second volume, however, both Rowson and her characters seem to forget this elaborately created mixed-race genealogy, firmly fixing the identity of Reuben and Rachel as white and English. By so doing, is Rowson accurately mirroring and implicitly mourning the failure of America to live up to its Revolutionary ideals? Or is she reinscribing and claiming the racism of the nation's founding? (Baym 1995, 162; Castiglia 1995, 39; Smith-Rosenberg 1993, 503).

The novel leaves itself open to both readings. Indeed, despite Rowson's invocation of American patriotism and the Revolutionary legacy in her preface, the status of the novel as a nationalistic project is equally ambiguous. As Nina Baym points out, Rowson "ends her story before the American Revolution begins, which means that her characters are still fully English" (Baym 1995, 162). Again, despite Rowson's preface, the novel's conclusion suggests that Rowson hoped to address readers back in England as well as American readers. The appearance of a Minerva Press London edition of the novel a year after the Boston edition supports this inference. Tellingly, this London edition omits the patriotic preface and its address to young readers "native" to America (Rowson 1799).

In the 1790s, then, Rowson's novels and their circulation were decidedly transatlantic, although the nature of her positioning shifted through and in response to changes in her own national status. While a subject of the English Crown, she wrote novels featuring events that transpired during the American Revolution based in part on her own years residing in America; she then ensured that American publishers reprinted those novels after she emigrated. After becoming an American resident, Rowson wrote a historical novel similarly spanning English and colonial American content. She was not quite yet a citizen in 1798, howeverthe citizenship status of women depended on that of their husbands, so Rowson became a citizen upon her husband's naturalization in 1804 (Davidson 1989, 167). She first published that historical novel in the United States, a young nation that had directed in its Constitution that "The Congress shall have the power: To promote the progress of science and useful arts, by securing, for limited times, to authors and inventors, the exclusive right to their respective writings and discoveries." In 1790, Congress enacted the first U.S. copyright statute, a law that extended protection only to works written by authors who were citizens or residents of the United States (Solberg 1906, 31-32). Because of Rowson's U.S. residence in 1798, her publisher was able to register a copyright for Reuben and Rachel, protecting his and Rowson's proprietary interest in the novel or, more accurately, Rowson's husband's proprietary interest (Gilreath 1987, 92). However, even a designedly "national" American novel like Reuben and Rachel, written and published after the founding of the Republic, celebrating its history, and protected under its laws, could cross the Atlantic. And, increasingly, in the nineteenth century, American printers and publishers devoted their resources to reprinting and distributing 
novels by British authors first published in London, something that U.S. copyright law allowed and even encouraged them to do without seeking permission from or making payments to those British authors (Barnes 1974; McGill 2003). As a result, more early nineteenth-century American readers read Sir Walter Scott's historical novels about England and Scotland than ever read Reuben and Rachel.

\section{References}

Bannet, Eve Tavor. 1999. The Theater of Politeness in Charlotte Lennox's BritishAmerican Novels. Novel 33:73-92.

Barnes, Elizabeth. 1997. States of Sympathy: Seduction and Democracy in the American Novel. New York: Columbia University Press.

Barnes, James J. 1974. Authors, Publishers, and Politicians: The Quest for an Anglo-American Copyright Agreement 1815-1854. Columbus: Ohio State University Press.

Baym, Nina. 1995. American Women Writers and the Work of History, 1790-1860. New Brunswick, NJ: Rutgers University Press.

Berg, Temma F. 1996. Getting the Mother's Story Right: Charlotte Lennox and the New World. Papers on Language and Literature 32:369-398.

Bissell, Benjamin. 1925. The American Indian in English Literature of the Eighteenth Century. New Haven, CT: Yale University Press.

Carlile, Susan. 2004. Expanding the Feminine: Reconsidering Charlotte Lennox's Age and The Life of Harriot Stuart. Eighteenth-Century Novel 4:103-137.

Castiglia, Christopher. 1995. Susanna Rowson's Reuben and Rachel: Captivity, Colonization, and the Domestication of Columbus. In Redefining the Political Novel: American Women Writers, 1797-1901, edited by Sharon M. Harris, 23-42. Knoxville: University of Tennessee Press.

Cowie, Alexander. 1948. The Rise of the American Novel. New York: American Book Company.

Davidson, Cathy N. 1986. Revolution and the Word: The Rise of the Novel in American. New York: Oxford University Press.

Davidson, Cathy N. 1989. The Life and Times of Charlotte Temple: The Biography of a Book. In Reading in America: Literature and Social History, edited by Cathy N. Davidson, 157-179. Baltimore: Johns Hopkins University Press.

Davis, Richard Beale. 1967. Arthur Blackamore: The Virginia Colony and the Early English Novel. Virginia Magazine of History and Biography 75: 22-34.

Ebersole, Gary L. 1995. Captured by Texts: Puritan to Postmodern Images of Indian Captivity. Charlottesville: University Press of Virginia.

Ellison, Julie. 1995. There and Back: Transatlantic Novels and Anglo-American Careers. In The Past as Prologue: Essays to Celebrate the Twenty-fifth Anniversary of ASECS, edited by Caria H. Hay and Syndy M. Conger, 303-324. New York: AMS.

Fiedler, Leslie A. 1960. Love and Death in the American Novel. New York: Criterion. 
Gilreath, James, ed. 1987. Federal Copyright Records, 1790-1800. Washington, DC: Library of Congress.

Hall, David D. 1996. Cultures of Print: Essays in the History of the Book. Amherst: University of Massachusetts Press.

Hayes, Kevin J. 1996. A Colonial Woman's Bookshelf. Knoxville: University of Tennessee Press.

Hayes, Kevin J. 1998. “Blackamore, Arthur.” Dictionary of Virginia Biography, edited by John T. Kneebone, J. Jefferson Looney, Brent Tarter, and Sandra Gioia Treadway, vol. i, pp. 516-517. Richmond: Library of Virginia.

Heilman, Robert Bechthold. 1937. America in English Fiction, 1760-1800. Baton Rouge: Louisiana State University Press.

Howard, Susan K. 1993. Identifying the Criminal in Charlotte Lennox's The Life of Harriot Stuart. Eighteenth-Century Fiction 5:137-152.

Howard, Susan K. 2005. Seeing Colonial America and Writing Home about It: Charlotte Lennox's Euphemia, Epistolarity, and the Feminine Picturesque. Studies in the Novel 37: 273-291.

Joseph, Betty. 2000. Replaying Crusoe/Pocahontas: Circum-Atlantic Stagings in The Female American. Criticism 42:317-335.

[Kimber, Edward]. 1754. The History of the Life and Adventures of Mr. Anderson. Containing His Strange Varieties of Fortune in Europe and America. Dublin: Richard James.

[Kimber, Edward]. 1998. Itinerant Observations in America, edited by Kevin J. Hayes. Newark: University of Delaware Press.

Lennox, Charlotte. 1995. The Life of Harriot Stuart, Written by Herself, edited by Susan Kubica Howard. Madison, NJ: Farleigh Dickinson University Press.

Loshe, Lillie Deming. 1907. The Early American Novel. New York: Columbia University Press.

Mason, Matthew, and Nicholas Mason. 2007. Introduction. In History of the Life and Adventures of Mr. Anderson, by Edward Kimber. Toronto: Broadview.

McBurney, William H. 1963. Four before Richardson: Selected English Novels, 1720-1727. Lincoln: University of Nebraska Press.

McGill, Meredith L. 2003. American Literature and the Culture of Reprinting, 18341853. Philadelphia: University of Pennsylvania Press.

Milne, W. Gordon. 1947. A Glimpse of Colonial America as Seen in an English Novel of 1754. Maryland Historical Magazine 42: 239-252.

Parker, Patricia L. 1986. Susanna Rowson. Boston: Twayne.

Perry, Ruth. 2004. Novel Relations: The Transformation of Kinship in English Literature and Culture, 1748-1818. New York: Cambridge University Press.

Rowson, Susanna. 1794. The Fille de Chambre: A Novel. Philadelphia: H. \& P. Rice.

Rowson, Susanna. 1798. Reuben and Rachel; or. Tales of Old Times. Boston: Manning and Loring.

Rowson, Susanna. 1799. Reuben and Rachel; or. Tales of Old Times: A Novel. London: Minerva Press, for William Lane. 
Rowson, Susanna. 1814. Rebecca, or. The Fille de Chambre: A Novel. Boston: R. P. \& C. Williams.

Rowson, Susanna. 1986. Charlotte Temple, edited by Cathy N. Davidson. New York: Oxford University Press.

Séjourné, Philippe. 1967. The Mystery of Charlotte Lennox: First Novelist of Colonial America (1727?-1804). Aix-en-Provence: Publications des Annales de la Faculté des Lettres.

Smith-Rosenberg, Carroll. 1993. "Subject Female: Authorizing American Identity." American Literary History 5: 481-511.

Solberg, Thorvald, ed. 1906. Copyright Enactments of the United States, 1783-1906. Washington, DC: Library of Congress.

Spengemann, William C. 1994. A New World of Words: Redefining Early American Literature. New Haven, CT: Yale University Press.

Stern, Julia A. 1997. The Plight of Feeling: Sympathy and Dissent in the Early American Novel. Chicago: University of Chicago Press.

Stevens, Laura M. 2005. Reading the Hermit's Manuscript: The Female American and Female Robinsoniades. In Approaches to Teaching Defoe's Robinson Crusoe, edited by Carl Fisher, 140-151. New York: Modern Language Association of America.

Vail, R. W. G. 1932. Susanna Haswell Rowson, the Author of Charlotte Temple: A Bibliographical Study. Proceedings of the American Antiquarian Society 42: 47-160.

Weil, Dorothy. 1976. In Defense of Women: Susanna Rowson (1762-1824). University Park: Pennsylvania State University Press.

Winans, Robert B. 1975. The Growth of a Novel-Reading Public in Late-EighteenthCentury America. Early American Literature 9: 267-275.

Winans, Robert B. 1983. Bibliography and the Cultural Historian: Notes on the Eighteenth-Century Novel. In Printing and Society in Early America, edited by William L. Joyce et al., 174-185. Worcester, MA: American Antiquarian Society.

Winkfield, Unca Eliza [pseud.]. 2001. The Female American, edited by Michelle Burnham. Toronto: Broadview.

Wolf, Edwin, 2nd. 1988. The Book Culture of a Colonial American City: Philadelphia Books, Bookmen, and Booksellers. Oxford: Clarendon.

Young, Arthur. The Adventures of Emmera. 1974. New York: Garland. 